\title{
Pilot project EroL: Erosion events caused by heavy rainfall in Markgräflerland- Recommended actions for affected communities
}

\author{
Jessica Kempf ${ }^{1}$, a , Nobert Billen² ${ }^{2}$ André Assmann${ }^{1}$, Patrick Blau ${ }^{3}$, Inga Nietz ${ }^{4}$ and Constanze Lehmann ${ }^{4}$ \\ ${ }^{1}$ geomer GmbH, Im Breitspiel 11B, 69126 Heidelberg, Germany \\ ${ }^{2}$ terra fusca ing. Billen, Lange \& Lehmann PartG, c/o Riedgrasweg 26, 70599 Stuttgart, Germany \\ ${ }^{3}$ BGU - Büro für Geoinformatik und Umwelttechnik GbR, Riehenstraße 51, 79594 Inzlingen, Germany \\ ${ }^{4}$ Landratsamt Lörrach, Palmstraße 3, 79539 Lörrach, Germany
}

\begin{abstract}
The foothill of the Black Forest, east of the river Rhine in the north of Basle, has a high potential for soil erosion hazards because of its topography and geology in combination with its land use. The district of Lörrach was often exposed to extreme erosion events caused by heavy rainfall in the past. On the one hand these events effected direct damages on buildings and infrastructures, on the other hand fertile topsoil was lost and sediment into waterways accumulated. As part of the German Strategy for Adaptation to Climate Change (DAS) the pilot project "EroL" (20182021) supports the district of Lörrach with a development of a risk management strategy. Thus, by generating hazard maps for soil erosion and pluvial flooding, risk characteristics for risk objects and a concept for risk management strategy, which are carried out in several workshops with the network of communal departments, agriculture and forestry, affected citizens, planners and rescue services management.
\end{abstract}

\section{Introduction}

The foothill of the Black Forest, east of the river Rhine in the north of Basle, has a high potential for soil erosion hazards because of its topography and geology (mostly loess) in combination with its land use. The district of Lörrach was often exposed to extreme erosion events caused by heavy rainfall in the past. On the one hand these events effected direct damages on buildings and infrastructures, on the other hand fertile topsoil was lost and sediment into waterways accumulated.

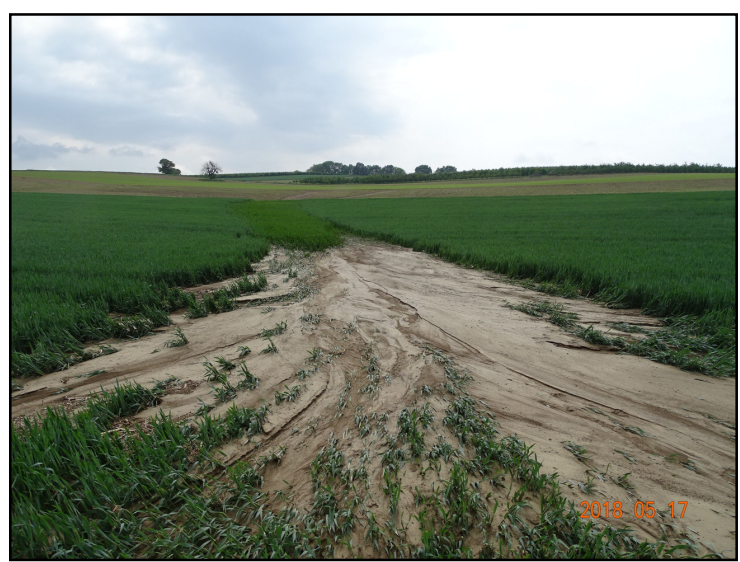

Figure 1. Erosion damages on arable land, Schallbach, northwest of Lörrach, Mai 2018 (Picture: P. Blau).
The most recent heavy rainfall events in Mai and July 2018 caused erosional damages on roads and arable land in the county of Lörrach (figure 1).

In the context of climate change an increase in extreme events such as heavy rainfall and erosional events is to be expected. Especially the combination of dry phases and subsequent convective precipitation generates extreme runoff and therefore high soil loss (see Sauer et al. 2013).

As pilot-project EroL is meant to assist the 12 participating municipalities with the adaption to climate change as well as optimally using and displaying the synergies between the often-separated fields of action "hazard control soil erosion" (LUBW 2011) and "Heavy rainfall risk management" (LUBW 2016).

\section{Approach}

EroL consists of three phases (see Figure 2). In the phase of hazard analyses (phase 1) erosional- and heavy rainfall hazard maps are generated. Building on that, riskobjects and -areas are identified in the following risk analysis (phase 2) and lead to the development of actions for the strategic concept (phase 3).

\footnotetext{
${ }^{\mathrm{a}}$ Corresponding author: jkempf@geomer.de

DOI 10.3311/FLOODRisk2020.13.3
} 


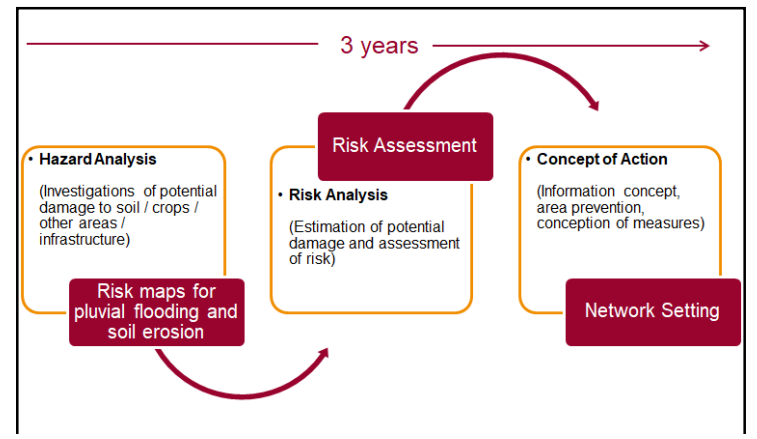

Figure 2. EroL Project Flow.

\subsection{Hazard Analysis}

In the first phase of the project hazard analysis are undertaken. Supported by the physically-based erosion model OpenLISEM (University of Twente 2018) and the raster-based hydraulic 2D model FloodArea ${ }^{\mathrm{HPC}}$ (geomer $\mathrm{GmbH}$ et al. 2017) erosional and pluvial flooding risk maps for the $300 \mathrm{~km}^{2}$ project area are created for different scenarios.

For the hydraulic and erosional modelling, the following base data are used:

- laserscan-data of a DEM with 1-m-resolution (HydTERRAIN)

- Land use and building cover are extracted from the register of real estate (ALKIS) and land use information (base DLM)

- Information about crop types on the areas of arable land extracted from municipal agricultural statistics for the year 2016 (Statistisches Landesamt BadenWürttemberg 2018)

- $\quad$ soil map 1:50.000 (BK50)

- KOSTRA-DWD-2010 heavy precipitation return times, revision (KOSTRA-DWD 2010R, Junghänel et al. 2017) (FOR EROSION MODELLING ONLY)

Following the guideline "Kommunales Starkregenrisikomanagement in Baden-Württemberg" (LUBW 2016), the hydraulic modelling occurs for three scenarios:

- "unusual", an event that is likely to occur once in 1050 years,

- "exceptional", an event that is likely to occur once in 50-200 years, and

- "extreme", an event that is likely to occur once in more than 200 years

OpenLISEM simulates three scenarios for the month of April with a 30-year period one-hour rainfall event (approx. $48 \mathrm{~mm} / \mathrm{h}$ ) with the Green-Ampt-infiltration method (Green and Ampt 1911). They differ only in terms of the distribution of crops on the arable land:

- real case 1: common crop rotation 1, i.e. random statistical crop distribution according to agricultural statistics 2016 with over $50 \%$ maize

- real case 2: common crop rotation 2, i.e. exchange of maize and winter cereal areas

- good case: favorable crop rotation, i.e. only winter cereals
The maximum erosion and accumulation are also derived from the scenarios "real case 1" and "real case 2" to the so-called "badbad case" scenario (see Figure 3).
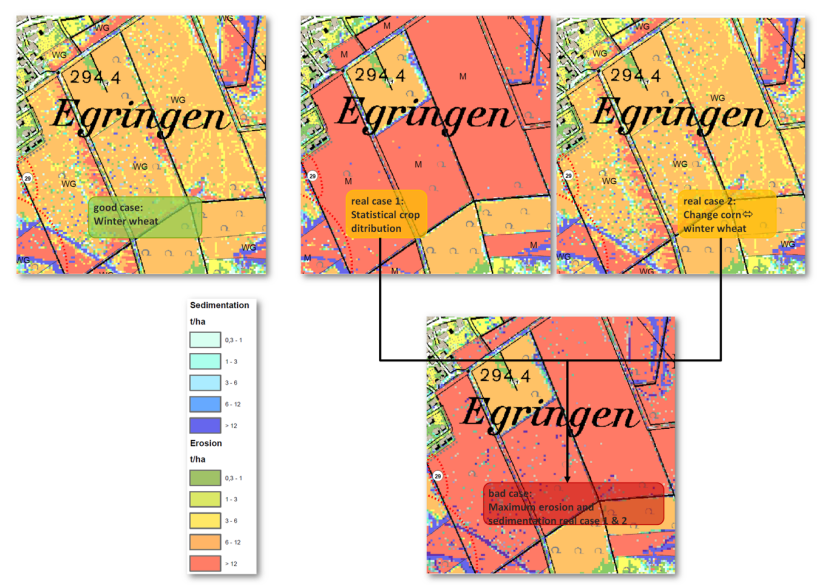

Figure 3. Erosion scenarios.

The validation of the created hazard maps takes place in the context of interdisciplinary workshops with the stakeholders involved from municipal departments, agriculture and forestry, specialist planners and the rescue and emergency services of civil protection. In addition, the simulated erosion scenarios can be validated with actual events from May 2018.

\subsection{Risk Analysis}

With the help of the hazard maps, a risk analysis is carried out in the next step. The risk hotspot areas and objects (see Figure 4) in the twelve municipalities in the district of Lörrach are identified, which are characterized by flooding, erosion or sedimentation during heavy rainfall events and are compared with past events.

Risk areas are areas of different sizes affected by one or more hazard aspects, both in the urban and in agricultural areas. In addition to the assessment of the risk, however, the vulnerability of the area is taken into account in the analyses, i.e. only if damage is to be expected, a risk must also be assumed. The indirect effects are also included here, e.g. when harmful substances leak as a result of flooding and cause consequential damage or accessibility or security of supply is restricted. Risk objects are public buildings such as kindergartens, schools, hospitals, retirement homes and fire brigades. 


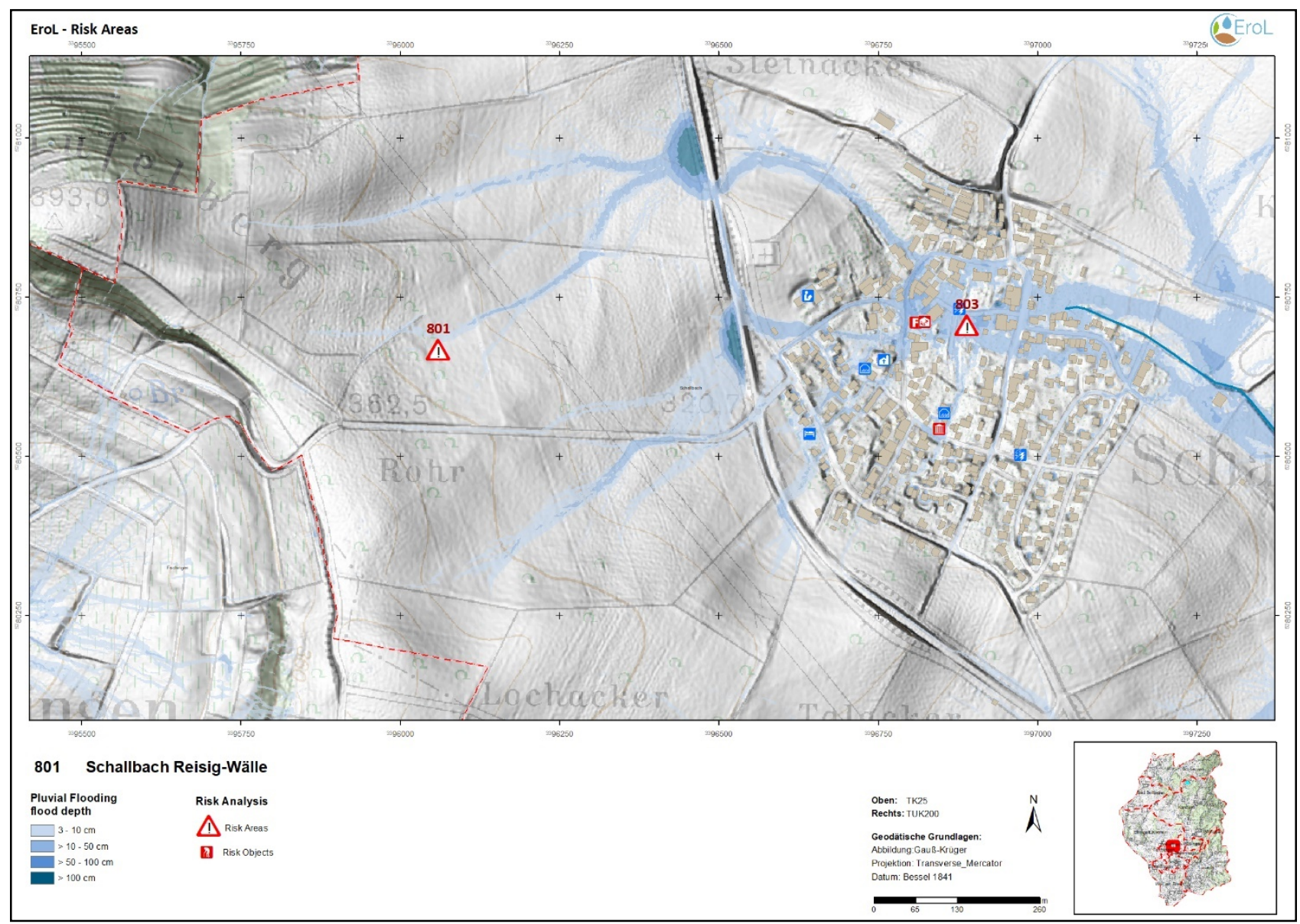

Figure 4. Example of map with flood depths and risk areas and risk objects (here: Schallbach northwest of Lörrach)

\subsection{Concept of action}

Finally, the risk objects (e.g. hospitals, schools) and risk areas are summarised in risk characteristics and a concept for risk management strategy is generated. It is carried out in agreement with the stakeholders of communal departments, agriculture and forestry, affected citizens, planners and rescue services management. The results of the project will be transferable on other comparable areas in the district and beyond.

The aim of the action plan is to prevent flooding and erosion events in the district of Lörrach as far as possible or to minimise the damage possible by means of appropriate precautionary measures in agricultural areas such as the installation of decentralized retention troughs or reduced soil cultivation (Billen et al. 2018).

\section{Results and conclusions}

When comparing the average soil losses on the arable land of the different scenarios due to heavy rainfall of approx. $48 \mathrm{~mm} / \mathrm{h}$, the "good case" with an average of $29 \mathrm{t} / \mathrm{ha}$ with the favourable crop rotation shows about $70 \%$ less erosion than the "bad case" with maize cultivation and on average 55\% less erosion compared to both "real case" scenarios with the common crop mix of equal summer and winter crops (see Figure 5).

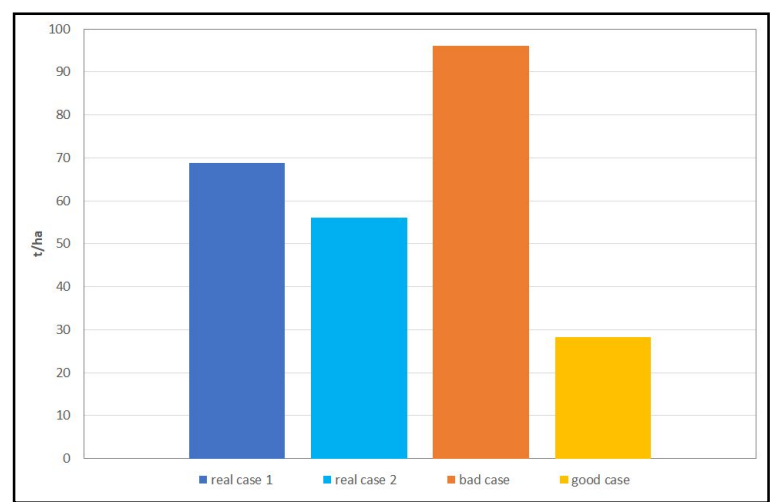

Figure 5. Mean soil erosion from the arable land calculated with LISEM for different scenarios (approx. $48 \mathrm{~mm} / \mathrm{h}$ )

The fluctuation range is 0 to $270 \mathrm{t} / \mathrm{ha}$. The simulated heavy rain and soil conditions in the investigated foothill zone are calculated to result in a loss of an average of $20 \mathrm{~m}^{3} / \mathrm{ha}$ of water storage capacity and $100 \mathrm{~kg}$ of soil N/ha.

The plausibility of the created erosion hazard maps with mappings of real erosion events in May 2018 resulted in good correlations of the erosion and sedimentation areas (see Figure 6). 


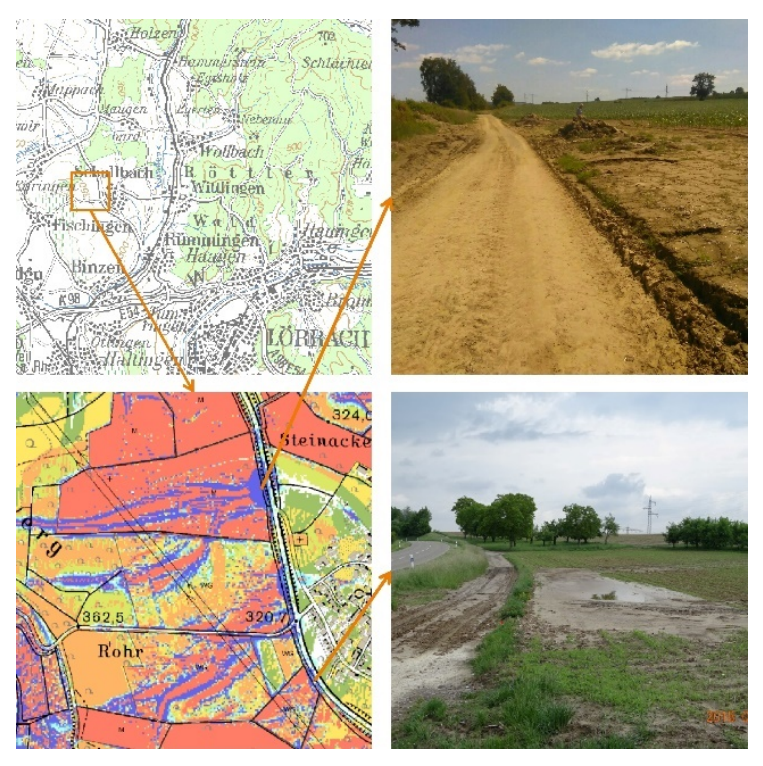

Figure 6. Good match of erosion and sedimentation areas in map and mapping (erosion event May 2018, Schallbach, photos: J. Kempf [above], P. Blue [bottom])

For the scenarios from the erosional and pluvial flooding modelling, 46 hazard risk maps are created on a scale of 1:5.000 and are available to the municipalities in the EroL-project area. These are also available via the geoportal of the district of Lörrach (https://gis.loerrachlandkreis.de/buergergis/synserver?project=Buerger_Umw elt\&client=flexjs\&user=internet).

The risk management strategies for the twelve municipalities in the district of Lörrach participating in EroL will be drawn up in 2020 and round tables with all stakeholders from agriculture, forestry, water management and civil protection will be established. These will also remain in place beyond the end of the project in order to ensure the implementation of the recommended measures by the district in cooperation with all stakeholders in the municipalities. As a lighthouse project, the results of EroL can be transferred to other municipalities within and outside the districts with a comparable territorial structure.

\section{References}

1. Billen, N., Puhlmann, H., Kempf, J. und Assmann, A. (2018). Land- und forstwirtschaftliche Maßnahmen zur Stärkung des Wasser- und Bodenrückhalts in Kommunen - Steckbriefe für die Praxis. - WBW Fortbildungsgesellschaft für Gewässerentwicklung $\mathrm{mbH}$, Karlsruhe.

2. geomer GmbH und Ruiz Rodriguez + Zeisler + Blank GbR (2017). FloodArea HPC-Desktop, Anwenderhandbuch, Heidelberg.

3. Green, W. H. and Ampt, G. A. (1911). Studies on soil physics I. - The flow of air and water through soils. $J$. Ag. Sci. 4: 1-24.

4. Junghänel, T., Ertel, H. und Deutschländer, T (2017). KOSTRA - DWD - 2010R. Bericht zur Revision der koordinierten Starkregenregionalisierung und auswertung des Deutschen Wetterdienstes in der Version 2010, Offenbach.
5. LUBW - Landesanstalt für Umwelt, Messungen und Naturschutz Baden-Württemberg (2016). Leitfaden Kommunales Starkregenrisikomanagement in BadenWürttemberg, Karlsruhe.

6. LUBW - Landesanstalt für Umwelt, Messungen und Naturschutz Baden-Württemberg (2011). Merkblatt Gefahrenabwehr bei Bodenerosion, Karlsruhe.

7. Sauer, T., Assmann, A. Billen, N., Fosser, G., Groh, S., Kempf, J., Dr. Schädler, G., Dr. Schipper, H. und Strauß, D. (2013): Kleinräumige Modellierung zur Abschätzung der Bodenerosion infolge von Starkniederschlägen. KLIWA-Berichte Heft 19, pp. 206-249.

8. Statistisches Landesamt Baden-Württemberg (2018). Agrarstrukturerhebung, Landwirtschaftszählung, Bodennutzungshaupterhebung. Stuttgart.

9. University of Twente (2018): OpenLISEM. MultiHazard Land Surface Process Model - Documentation \& User Manual. Twente.

The lighthouse project "EroL" will be funded from 2018 to 2021 as part of the German Adaptation Strategy to the Consequences of Climate Change (DAS) by the Federal Ministry for the Environment, Nature Conservation and Nuclear Safety (BMU) (funding code 03DAS111). 